\title{
PENERAPAN MODEL BASED LEARNING UNTUK MENINGKATKAN KEMAMPUAN PEMECAHAN MASALAH
}

\author{
Tiur Malasari \\ Dosen Matematika FMIPA UNIMED \\ Surel: tiur.malasari@gmail.com
}

\begin{abstract}
Abstrak
Penelitian ini bertujuan untuk meningkatkan hasil belajar matematika melalui pembelajaran based learning. Disamping ini penerapan pembelajaran based learning juga dapat meningkatkan partisipasi mahasiswa pembelajaran. Subjek penelitian ada sebanyak 25 orang, yaitu mahasiswa yang mengambil matakuliah matematika keuangan. Hasil penelitian menunjukkan pada sikur pertama, diperoleh selisih skor rata-rata postest dengan skor rata rata-rata pretest diperoleh sebesar 34,68 dengan tingkat kemampuan pemecahan masalah secara klasikal 12\%. Setelah diberi tindakan I menggunakan model problem Based Learning rata-rata nilai tes kemampuan pemecahan masalah I meningkat menjadi $61,6 \%$ dengan tingkat kemampuan pemecahan masalah secara klasikal 36\%. Ini berarti terjadi peningkatan $24 \%$ dari pretest yang dilaksanakan. Kemudian setelah pemberian tindakan II, diperoleh nilai rata-rata tes kemampuan pemecahan masalah II mahasiswa adalah $71,8 \%$ dengan tingkat kemampuan pemecahan masalah secara klasikal yang berarti mengalami peningkatan sebesar $44 \%$ dari tes kemampuan pemecahan masalah I.
\end{abstract}

Kata kunci: Metode Based Learning, Hasil Belajar

\section{PENDAHULUAN}

Pendidikan sangatlah penting dalam mencerdaskan anak bangsa, karena melalui pendidikan terciptalah sumber daya manusia yang terdidik dan mampu menghadapi perubahan zaman yang semakin cepat. Memasuki era teknologi dan globalisasi ini diperlukan sumber daya manusia yang kreatif, berpikir sistematis, logis, dan konsisten, dapat bekerja sama dan tidak putus asa. Hal ini sejalan dengan pendapat Sumaatmadja (1998: 106) yang mengemukakan bahwa : "pendidikan merupakan upaya meningkatkan salah satu aspek kualitas SDM. SDM yang berkualitas, khususnya dari aspek pendidikan menjadi modal dasar bahkan menjadi modal utama bagi pembangunan nasional yang menuntut SDM Indonesia yang berkualitas dan berkemampuan kompetitif". Untuk memperoleh sifat yang demikian perlu diberikan pendidikan yang berkualitas dengan bermacam-macam ilmu pengetahuan. Salah satu ilmu pengetahuan yang merefleksikan sifat-sifat tersebut adalah matematika, karena matematika merupakan ilmu dasar dan melayani hampir setiap ilmu. Matakuliah matematika keuangan 
diajarkan di Jurusan Matematika FMIPA Unimed pada semester 5 dengan bobot kredit 3 sks. Berdasarkan data evaluasi diri Jurusan Matematika, nilai mahasiswa pada matakuliah matematika keuangan cenderung rendah. Rendahnya nilai pada matakuliah Matematika keuangan tersebut dipengaruhi oleh berbagai faktor. Salah satu faktor yang menyebabkan rendahnya nilai tersebut adalah mahasiswa kurang memahami konsep matakuliah matematika keuangan sehingga mahasiswa mengalami kesulitan dalam menyelesaikan soal cerita matematika, dan kesulitan menentukan langkah-langkah yang harus ditempuh dalam membuat kalimat matematika. Abdurrahman (2003: 257) mengemukakan bahwa : "Dalam menyelesaikan soal-soal cerita banyak mahasiswa yang mengalami banyak kesulitan. Kesulitan tersebut tampaknya terkait dengan pengajaran yang menuntut mahasiswa membuat kalimat matematika tanpa terlebih dahulu memberikan petunjuk tentang langkah-langkah yang harus ditempuh". Kesulitan dalam belajar matematika keuangan mengakibatkan kemampuan pemecahan masalah mahasiswa rendah. Mahasiswa cenderung menghafalkan konsep-konsep matematika sehingga kemampuan mahasiswa dalam memecahkan masalah sangat kurang.

Adanya kendala tersebut menjadi faktor yang mempengaruhi hasil belajar siswa pada matakuliah Program Linier. Oleh karena itu diperlukan suatu tindakan untuk memperbaiki proses pembelajaran, diantaranya memilih model pembelajaran yang efektif, dan membuat mahasiswa lebih aktif dalam proses pembelajaran sehingga diharapkan terjadinya peningkatan hasil belajar. Salah satu model pembelajaran yang sesuai dengan kurikulum 2006 yang dikembangkan sekarang adalah Pembelajaran Berbasis Masalah (Problem-BasedLearning). Pengajaran ini menggunakan masalah dunia nyata sebagai suatu konteks belajar bagi siswa tentang cara berfikir kritis dan ketrampilan pemecahan masalah.

PBL merupakan salah satu model pembelajaran inovatif yang dapat memberikan kondisi belajar aktif kepada mahasiswa, melibatkan mahasiswa untuk memecahkan suatu masalah melalui tahap-tahap metode ilmiah sehingga mahasiswa dapat mempelajari pengetahuan yang berhubungan dengan masalah tersebut dan sekaligus memiliki keterampilan untuk memecahkan masalah. Seperti yang diungkapkan Richard I. Arends (2008: 43) : "PBL membantu mahasiswa untuk mengembangkan keterampilan berpikir dan keterampilan mengatasi masalah, mempelajari peran-peran orang dewasa dan menjadi mahasiswa yang mandiri".

Dengan menerapkan model PBL (Problem Based Learning), maka diharapkan dapat mengatasi kesulitan mahasiswa dalam 
mempelajari matematika dan mahasiswa dapat menemukan sendiri penyelesaian masalah dari suatu pokok bahasan. Sehingga mahasiswa akan termotivasi untuk belajar matematika dan mampu mengembangkan ide dan gagasan mereka dalam menyelesaikan permasalahan matematika yang diorganisaikan di dalam situasisituasi kehidupan nyata. Matematika keuangan merupakan topik yang berhubungan dengan kehidupan sehari-hari dan juga materi yang sulit dikuasai oleh mahasiswa. Hal ini diakibatkan karena keadaan mahasiswa yang terbiasa belajar berpusat pada dosen yang menggunakan metode ceramah.

Tujuan yang ingin dicapai dari penelitian ini yaitu: Adapuan tujuan yang dilakukan dalam penelitian ini adalah : "Untuk mengetahui peningkatan kemampuan pemecahan masalah dengan menerapkan model PBL (Problem based Learning) pada Matakuliah Matematika Keuangan di Jurusan Matematika FMIPA UNIMED”.

Kegiatan pembelajaran diselenggarakan dalam hal pembentukan watak dan meningkatkan mutu kehidupan peserta didik. Kegiatan pembelajaran juga mengembangkan kemampuan mengetahui, memahami melakukan sesuatu, dan hidup dalam kebersamaan. Pada keseluruhan proses pendidikan di lembaga pendidikan, pembelajaran merupakan aktivitas yang paling utama. Dalam pembelajaran seorang pengajar berhadapan dengan sejumlah peserta didik dengan berbagai macam latar belakang, sikap, dan potensi, yang semua itu berpengaruh terhadap kebiasaannya dalam mengikuti pembelajaran. Menurut Surya (dalam Sinurat 2009:10) mengemukakan bahwa : "Pembelajaran adalah suatu proses yang dilakukan oleh individu untuk memperoleh suatu perubahan perilaku yang baru secara keseluruhan, sebagai hasil dari pengalaman individu itu sendiri dalam interaksi dengan lingkungannya".

Kemudian menurut Degeng (dalam Uno 2008: 2) menyatakan bahwa : "Pembelajaran atau pengajaran adalah upaya untuk membelajarkan peserta didik". Dalam pengertian ini secara implisit dalam pengajaran terdapat kegiatan memilih, menetapkan, mengembalikan metode untuk mencapai hasil pengajaran yang diinginkan."Sedangkan matematika merupakan ilmu yang membutuhkan disiplin yang ketat dalam mempelajarinya, juga dipandang sebagai suatu bahasa, struktur logika, batang tubuh dari bilangan dan ruang, rangkaian metode untuk menarik kesimpulan, esensi ilmu terhadap dunia fisik dan sebagai aktivitas intelektual. Pada hakikatnya matematika adalah suatu ilmu yang cara berpikirnya abstrak dan deduktif. Yang lebih menekankan pada penguasaan konsep dan merupakan landasan untuk mempelajari materi berikutnya. Uno (2008: 124-125) mengemukakan 
bahwa :"Mata pelajaran matematika menekankan penguasaan konsep dan algoritma di samping kemampuan memecahkan masalah. Di samping itu, matematika juga bersifat hierarkis yaitu suatu materi merupakan prasyarat untuk mempelajari materi berikutnya".

Dalam pembelajaran matematika peserta didik harus berperan aktif. Hubungan-hubungan antara konsep-konsep dan struktur dari matematika yang dipelajari akan lebih mudah dipahami bila mereka mempraktekkan sendiri upaya penemuannya. Pendapat ini didukung oleh Semiawan (dalam Sinurat 2009: 12) : "Anak-anak mudah memahami konsep-konsep yang rumit dan abstrak jika disertai dengan contoh-contoh konkrit, contoh-contoh yang wajar sesuai dengan situasi dan kondisi yang dihadapi, dengan mempraktekkan sendiri upaya penemuan konsep melalui perlakuan terhadap kenyataan fisik, melalui penanganan benda yang benar-benar nyata. Perkembangan pikiran (kognitif) anak sesungguhnya dilandasi oleh gerakan dan perbuatan".

Kebanyakan peserta didik mengalami kesulitan dalam mengaplikasikan matematika ke dalam situasi kehidupan real. Hal lain yang menyebabkan sulitnya matematika bagi peserta didik adalah karena pembelajaran matematika kurang bermakna. Pengajar dalam pembelajarannya di kelas tidak mengaitkan dengan skema yang telah dimiliki oleh peserta didik dan peserta didik kurang diberikan kesempatan untuk menemukan kembali dan mengkonstruksi sendiri ide-ide matematika.

Pemecahan masalah memerlukan strategi dalam menyelesaikannya. Kebenaran, ketepatan, keuletan, dan kecepatan adalah suatu hal yang diperlukan dalam penyelesaian masalah. Keterampilan peserta didik dalam menyusun suatu strategi adalah suatu kemampuan yang harus dilihat oleh pengajar. Jawaban benar bukan standar ukur mutlak, namun proses yang lebih penting dari mana peserta didik mendapatkan jawaban tersebut.

Pemecahan masalah juga merupakan bagian dari strategi belajar mengajar yang sangat penting terutama dalam kegiatan belajar mengajar matematika. Hal ini seperti yang dikemukakan oleh Hudojo (2001: 165) menyatakan bahwa : "Pemecahan masalah mempunyai fungsi yang penting di dalam kegiatan belajar mengajar matematika. Melalui pemecahan masalah peserta didik-peserta didik dapat berlatih dan mengintegrasikan konsep-konsep, teorema-teorema dan keterampilan yang telah dipelajari”.

Trianto (2007:

mengemukakan bahwa : "Model pembelajaran berdasarkan masalah (PBL) merupakan suatu model pembelajaran yang didasarkan pada banyaknya permasalahan yang membutuhkan penyelidikan autentik yakni penyelidikan yang membutuhkan penyelesaian nyata dari permasalahan nyata". Peserta 
didik berusaha sendiri untuk mencari pemecahan masalah serta pengetahuan yang menyertainya, menghasilkan pengetahuan yang benar-benar bermakna. Suatu konsekuensi logis, karena dengan berusaha untuk mencari pemecahan masalah secara mandiri akan memberikan suatu pengalaman konkret, dengan pengalaman tersebut dapat digunakan pada pemecahan masalah serupa, karena pengalaman itu memberi makna tersendiri bagi peserta didik".

Mengajar peserta didik untuk menyelesaikan masalah memungkinkan peserta didik itu menjadi lebih analitik di dalam mengambil keputusan dalam kehidupan. Dengan kata lain, bila seorang peserta didik dilatih untuk menyelesaikan masalah, maka peserta didik itu akan mampu mengambil keputusan sebab peserta didik itu menjadi mempunyai banyak keterampilan tentang bagaimana mengumpulkan informasi yang relevan, menganalisis informasi dan menyadari betapa perlunya meneliti kembali hasil yang telah diperolehnya. Ada empat langkah pemecahan masalah antara lain (1) Memahami masalah. Tanpa adanya pemahaman masalah yang diberikan, peserta didik tidak mungkin mampu menyelesaikan masalah tersebut dengan benar. Adapun yang dapat dipahami dari permasalahan yang ada adalah masalah yang diketahui dan apa yang ditanya. Merencanakan penyelesaian. Setelah peserta didik dapat memahami masalahnya dengan benar, selanjutnya mereka harus mampu menyusun rencana penyelesaian masalah. Pada umumnya semakin bervariasi pengalaman mereka, ada kecenderungan peserta didik lebih kreatif dalam menyusun rencana penyelesaian suatu masalah. Mencari hubungan antara yang diketahui dengan yang ditanya, bagaimana mengetahui kaitannya dengan masalah itu.(3)Menyelesaikan masalah sesuai rencana. Jika rencana penyelesaian suatu masalah telah dibuat, baik secara tertulis atau tidak, selanjutnya dilakukan penyelesaian masalah sesuai dengan rencana yang dianggap paling tepat. Memeriksa setiap langkah penyelesaiannya. Apakah setiap langkahnya benar? Apakah penyelesaiannya dapat membuktikan bahwa hal itu benar?. (4)Melakukan pengecekan kembali terhadap semua langkah yang telah dikerjakan. Menyelidiki penyelesaian yang telah dilaksanakan pada fase pertama sampai dengan penyelesaian fase ketiga. Mengecek hasilnya, dengan cara seperti ini maka berbagai kesalahan yang tidak perlu dapat terkoreksi kembali sehingga peserta didik dapat sampai pada jawaban yang benar sesuai dengan masalah yang diberikan".

Ada 6 langkah utama dalam pembelajaran kooperatif. Pembelajaran dimulai dengan dosen menyampaikan tujuan pembelajaran dan motivasi mahasiswa belajar dan diakhiri dengan persentasi hasil kerja kelompok, atau evaluasi 
tentang apa yang telah mereka pelajari dan memberi penghargaan terhadap usaha-usaha kelompok maupun individu. Adapun langkah pembelajaran kooperatif, dirangkum pada Tabel 1 berikut:

Tabel 1. Sintak Model Pembelajaran Kooperatif

\begin{tabular}{|c|c|}
\hline Fase-fase & Tingkah Laku Dosen \\
\hline $\begin{array}{l}\text { Fase } 1 \\
\text { Menyampaikan tujuan dan } \\
\text { motivasi mahasiswa } \\
\text { Fase } 2 \\
\text { Menyajikan informasi } \\
\text { Fase } 3 \\
\text { Mengorganisasi mahasiswa } \\
\text { kedalam kelompok-kelompok } \\
\text { belajar } \\
\text { Fase } 4 \\
\text { Membimbing kelompok } \\
\text { bekerja dan belajar. } \\
\text { Fase } 5 \\
\text { Evaluasi }\end{array}$ & $\begin{array}{l}\text { Dosen menyampaikan tujuan pembelajaran } \\
\text { yang ingin dicapai pada pelajaran tersebut dan } \\
\text { memotivasi mahasiswa belajar } \\
\text { Dosen menyajikan informasi kepada } \\
\text { mahasiswa melalui demonstrasi/bahan bacaan. } \\
\text { Dosen menjelaskan kepada mahasiswa } \\
\text { bagaimana caranya membentuk kelompok } \\
\text { belajar dan membantu setiap kelompok agar } \\
\text { melakukan transisi secara efisien } \\
\text { Dosen membimbing kelompok belajar pada } \\
\text { saat mereka mengerjakan tugas mereka } \\
\text { Dosen mengevaluasi hasil belajar tentang } \\
\text { materi yang telah dipelajari atau setiap } \\
\text { kelompok merpresentasikan hasil kerjanya. } \\
\text { Dosen mencari cara menghargai baik usaha } \\
\text { maupun hasil belajar individu dan kelompok. }\end{array}$ \\
\hline
\end{tabular}

METODOLOGI PENELITIAN

Penelitian ini dilaksanakan pada mahasiswa jurusan matematika yang mengambil matakuliah matemátika keuangan Semester Ganjil TA 2010/2011. Tempat penelitian dilakukan pada Ruang
Kuliah Jurusan matematika, yang diaksanakan pada Hari selasa pukul $12.00-14.30$.

Penelitian bertujuan meningkatkan mutu pembelajaran matakuliah matematika keuangan melalui strategi pembelajaran based 
learning. Proses upaya peningkatan mutu pembelajaran mengikuti model Hopkins (1993:48) yaitu : siklus perencanaan, aksi (tindakan), observasi (pengamatan), dan refleksi terhadap tindakan, dan perencanaan ulang (revisi rencana dan revisi tindakan).

Peneliti berperan sebagai active participant observer dan langsung sebagai pengajar. Pencapaian target meningkatkan mutu pembelajaran melalui strategi pembelajaran kooperatif melalui langkah-langkah sistematis yang menyertakan mahasiswa secara aktif.

Teknik pengumpulan data yang dilakukan berpedoman pada penelitian kualitatif dan kuantitatif. Pengumpulan data dengan paradigma penelitian kualitatif menggunakan lembar observasi, pengumpulan berbagai dokumen, dan pengamatan. Kegiatan utama dari setiap alat yang digunakan dalam kegiatan pengumpulan data memiliki tujuan yang sama dalam aspek yang berbeda. Paradigma kuantitatif digunakan untuk data hasil belajar mahasiswa sesuai dengan kompetensi yang dituliskan dalam bentuk tes kognitif. Tes kognitif mahasiswa adalah seperangkat tes objektif berupa pilihan ganda dan esai.

\section{HASIL PENELITIAN DAN PEMBAHASAN}

Hasil implementasi kegiatan penelitian ini, diuraikan dalam tahapan siklus pembelajaran di kelas.
Tahapan siklus yang dilakukan sebagai berikut:

\section{A. Siklus Pertama (dua Pertemuan)}

Siklus pertama terdiri atas empat tahap yaitu: perencanaan, pelaksanaan, observasi dan repleksi serta replanning. Adapun implementasi yang dilakukan yaitu:

\section{a. Perencanaan (Planning).}

Tahap ini dilakukan kegiatan perencanaan sebelum pembelajaran. Adapun usaha dalam kegiatan tersebut yaitu: 1) melakukan analisis kurikulum untuk menentukan standar kompetensi dan kompetensi dasar. 2) membahas dan membuat tes untuk mengukur kompetensi dasar. 3) membuat dan mengetahui nama-nama mahasiswa yang mengambil matakuliah sebagai dasar membuat kelompok diskusi. 4) Membuat rencana pembelajaran dan 5) Membuat bahan diskusi kelompok mahasiswa sesuai materi matakuliah.

b. Pelaksanaan (Acting). Siklus pertama penelitian ini dilakukan dua kali pertemuan dengan materi pelajaran tentang bunga majemuk. Setiap pembelajaran dibagi atas tiga tahap yaitu: tahap pendahuluan, tahap inti dan tahap penutup. Pada tahap pendahuuan disampaikan 
tujuan perkuliahan, memotivasi siswa tentang pentingnya materi yang dipelajari, membangkitkan pengetahuan awal mahasiswa, menjelaskan tugas yang dikerjakan. Tahap pendahuluan ini membutuhkan waktu setikat 15 menit. Pada tahap inti, dilakukan pelaksanaan perkuliahan model pemecahan masalah, yang diawali dengan tes awal (pretes) sebelum masuk materi kuliah. Kemudian peneliti memperkenalkan model pembelajaran yang akan dilaksanakan, dan memberi kesempatan kepada mahasiswa untuk bertanya tentang pembelajaran tersebut. Lebih lanjut mahasiswa melakukan diskusi dalam kelompok masing-masing dan menyusun hasil diskusinya. Pada saat mahasiswa melakukan aktivitas secara berkelompok, peneliti memantau aktivitas tersebut sambil mengisi embar pengamatan aktivitas. Apabila ada kelompok yang mengalami kendala daam melaksanakan pembelajaran, peneliti memberikan bantuan agar aktivitas terus berjalan. Pada bagian penutup, peneliti melakukan refleksi dengan menyimpulkan materi kuliah yang baru didiskusikan dan memberi tugas kepada masingmasing mahasiswa. Kemudian ditugaskan masing-masing kelompok diskusi membuat laporan dan dipersentasekan pada pertemuan berikutnya.

\section{c. Observasi dan evaluasi} (Observation and evaluation). Kegiatan observasi dilaksanakan selama proses perkuliahan berlangsung. Selama observasi, peneliti mencatat kegiatan proses dan menilai hasil tindakan dan partisipasi masiswa dalam kegiatan inti pembelajaran. Hasil observasi pada siklus pertama, skor pretes dan postes dengan materi vektor disajikan berikut: 

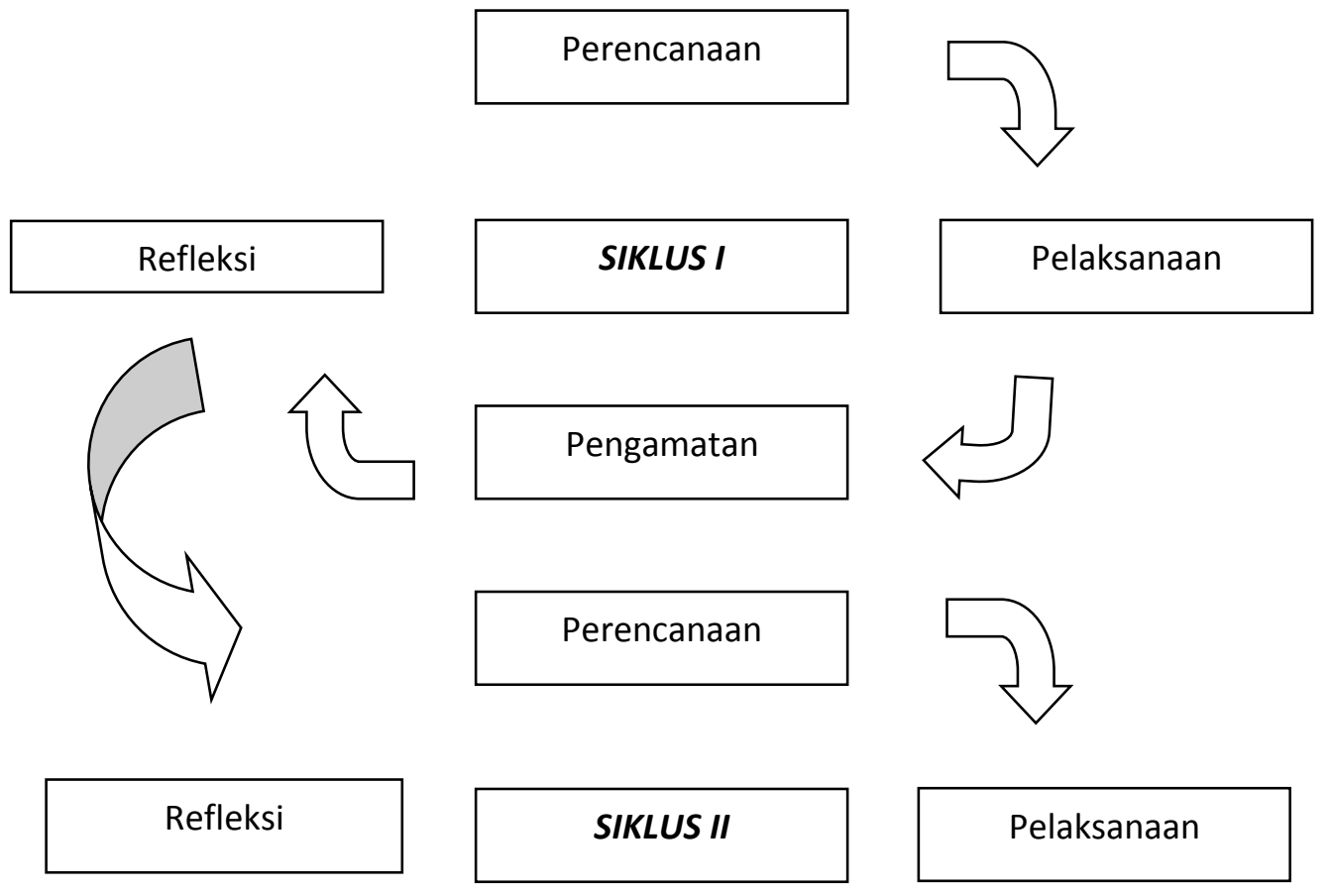

Pelaksanaan
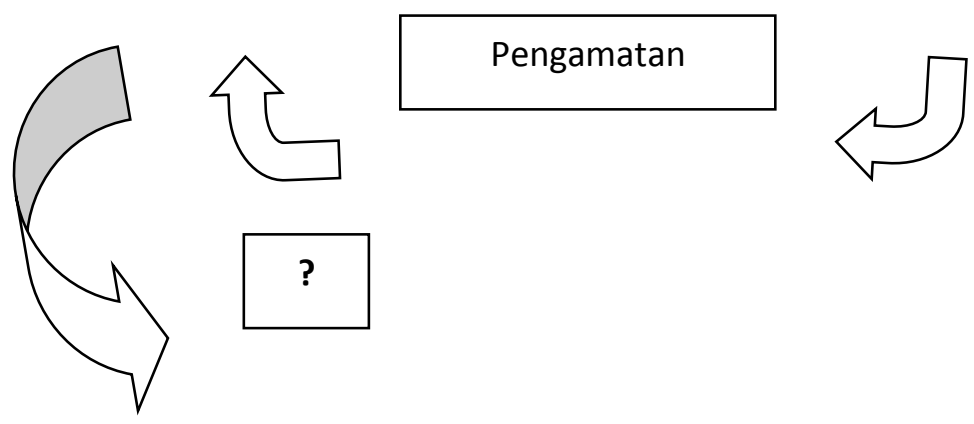

d) Refleksi dan Perencanaan Ulang (Refection and Replanning). Berdasarkan hasil dan uraian pada siklus pertama kegiatan penelitian ini, maka dilakukan perencanaan ulang untuk pelaksanaan pembelajaran siklus kedua. Adapun beberapa kelemahan yang terjadi pada pembelajaran siklus pertama dengan materi vektor yaitu: 1) Mahasiswa belum terbiasa dengan kondisi pembelajaran dengan model based learning. Mereka belum antusias dalam perkuliahan. 2) Hasil evaluasi pada siklus pertama mencapai skor postest sebesar 61.6\%. 3) Masih ada mahasiswa yang belum menyelesaikan tugas pada waktu yang ditentukan. 4) Masih ada mahasiswa yang kurang mengerti terhadap materi kuliah khususnya tentang bunga majemuk. 5) Masih ada mahasiswa yang kurang paham tentang proses perkuliahan menngunakan model based learning. 


\section{B. Siklus Kedua (dua Pertemuan)}

Siklus kedua terdiri atas empat tahap yaitu: perencanaan, pelaksanaan, observasi dan repleksi serta replanning. Adapun implementasi yang dilakukan pada siklus kedua diuraikan sebagai berikut :

\section{a) Perencanaan (Planning).}

Pada tahap kedua peneliti melakukan kegiatan perencanaan yang dilakukan berdasarkan pada siklus pertama. Adapun usaha dalam kegiatan tersebut yaitu: 1) Memberikan motivasi kepada mahasiswa agar lebih berpartisipasi dalam perkuliahan. 2) Lebih intensif membimbing mahasiswa/kelompok

mahasiswa yang mengalami kesulitan dalam perkuliahan, 3) Memberikan pengakuan atau penghargaan kepada mahasiswa atau kelompok yang mampu mengikuti perkuliahan.

\section{b) Pelaksanaan (Acting).Pada} siklus kedua penelitian ini dilakukan dua kali pertemuan dengan materi pelajaran tentang konsep anuitas. Setiap pembelajaran dibagi atas tiga tahap yaitu: tahap pendahuluan, tahap inti dan tahap penutup. Pada tahap pendahuuan disampaikan tujuan perkuliahan, memotivasi siswa tentang pentingnya materi yang dipelajari, membangkitkan pengetahuan awal mahasiswa, menjelaskan tugas yang dikerjakan. Tahap pendahuluan ini membutuhkan waktu setikat 15 menit. Pada tahap inti, dilakukan pelaksanaan perkuliahan model kooperatif, yang diawali dengan tes awal (pretes) sebelum masuk materi kuliah. Kemudian memberi kesempatan kepada mahasiswa untuk bertanya tentang kendalam pembelajaran dengan model based learning tersebut. Lebih lanjut mahasiswa melakukan diskusi dalam kelompok masing-masing dan menyusun hasil diskusinya. Pada saat mahasiswa melakukan aktivitas secara berkelompok, peneliti memantau aktivitas tersebut sambil mengisi lembar pengamatan aktivitas. Apabila ada kelompok yang mengalami kendala dalam melaksanakan pembelajaran, peneliti memberikan bantuan agar aktivitas terus berjalan. Pada bagian penutup, peneliti melakukan refleksi dengan menyimpulkan materi kuliah yang baru didiskusikan dan memberi tugas kepada masingmasing mahasiswa dan membuat laporan dan dipersentasekan pada pertemuan berikutnya. 


\section{c) Observasi dan evaluasi} (Observation and evaluation).

Kegiatan observasi

dilaksanakaan selama proses perkuliahan berlangsung. Selama observasi, peneliti mencatat kegiatan proses dan menilai hasil tindakan dan partisipasi mahasiswa dalam kegiatan inti pembelajaran. Hasil observasi pada siklus kedua, skor pretes dari materi anuitas

Berdasarkan hasil penelitian, sebelum diberi tindakan rata-rata pretest adalah 34,68 dengan tingkat kemampuan pemecahan masalah secara klasikal 12\%. Setelah diberi tindakan I menggunakan model problem based learning rata-rata nilai tes kemampuan pemecahan masalah I meningkat menjadi $61,6 \%$ dengan tingkat kemampuan pemecahan masalah secara klasikal 36\%. Ini berarti terjadi peningkatan $24 \%$ dari pretest yang dilaksanakan. Kemudian setelah pemberian tindakan II, dimana pembelajaran masih tetap dengan penerapan model problem based learning diperoleh nilai ratarata tes kemampuan pemecahan masalah II mahasiswa adalah $71,8 \%$ dengan tingkat kemampuan pemecahan masalah secara klasikal $80 \%$ yang berarti mengalami peningkatan sebesar $44 \%$ dari tes kemampuan pemecahan masalah.

d) Refleksi (Refection). Adapun keberhasilan yang diperoleh pada siklus kedua yaitu sebagai berikut: 1) Aktivitas

mahasiswa dalam perkuliahan sudah mengarah pada pembelajaran yang aktif. 2) Mahasiswa sudah mampu memecahkan masalah untuk menyelesaikan soal-soal sesuai materi perkuliahan, 3) Mahasiswa sudah lebih berpartisipasi dalam kegiatan perkuliahan, 4) Semakin meningkatnya pemahaman mahasiswa terhadap materi perkulihan.

\section{Pembahasan}

Penerapan model problem based learning dapat meningkatkan kemampuan pemecahan masalah matematika mahasiswa. Berdasarkan hasil penelitian, sebelum diberi tindakan rata-rata pretest adalah 34,68 dengan tingkat kemampuan pemecahan masalah secara klasikal 12\%. Setelah diberi tindakan I menggunakan model problem based learning rata-rata nilai tes kemampuan pemecahan masalah I meningkat menjadi $61,6 \%$ dengan tingkat kemampuan pemecahan masalah secara klasikal 36\%. Ini berarti terjadi peningkatan $24 \%$ dari pretest yang dilaksanakan. Kemudian setelah pemberian tindakan II, dimana pembelajaran masih tetap dengan penerapan model problem based learning diperoleh nilai ratarata tes kemampuan pemecahan masalah II mahasiswa adalah $71,8 \%$ dengan tingkat kemampuan pemecahan masalah secara klasikal $80 \%$ yang berarti mengalami 
peningkatan sebesar $44 \%$ dari tes kemampuan pemecahan masalah I.

Ternyata dengan penerapan model problem based learning pada mata kuliah matematika keuangan mampu meningkatkan kemampuan pemecahan masalah matematika mahasiswa dalam menyelesaikan soal-soal matematika keuangan. Hal ini terlihat dari hasil tes yang diperoleh mahasiswa setelah dilakukan pembelajaran dengan menerapkan model problem based learning. Model problem based learning yang bercirikan pengajuan pertanyaan atau masalah, memusatkan pada keterkaitan antar disiplin, penyelidikan autentik, kerja sama, mampu membantu mahasiswa mengatasi masalah-masalah matematika sehingga kemampuan pemecahan masalah matematika meningkat.

\section{SIMPULAN DAN SARAN \\ Simpulan}

Berdasarkan hasil penelitian dan pembahasan yang diuraikan pada bab sebelumnya, maka kesimpulan penelitian ini disajikan sebagai berikut: 1) Penggunaan model based learning dapat meningkatkan hasil belajar mahasiswa. Hal ini dapat ditunjukkan berdasarkan pada siklus kedua terdapat selisih skor rata-rata hasil belajar sebesar $44 \% \quad .2)$ Mahasiswa menjadi lebih aktif dalam perkuliahan, hal ini terlihat dengan keaktifan atau partisipasi mahasiswa dalam mengikuti perkuliahan. Mahasiswa lebih rileks dengan suasana menyenangkan dalam mendiskusikan materi perkuliahan, 3) Semangat mahasiswa untuk mencari informasi lain meningkat, hal ini ditunjukkan dengan banyaknya dan beragam buku (sumber belajar) yang digunakan mahasiswa untuk mengkaji materi perkulihan, 4) Secara umum, berdasarkan hasil wawancara, mahasiswa mengemukakan bahwa model pembelajaran dengan pemecahan masalah membuat mahasiswa lebih senang untuk mengikuti perkuliahan. Hal ini menunjukkan bahwa model pembelajaran based learning membuat suasana perkuliahan lebih bermakna dalam menyajikan materi.

\section{Saran}

Dari hasil yang diperoleh pada penelitian ini, membuktikan bahwa model pemebelajaran based learning dapat meningkatkan mutu perkuliahan dan hasil belajar mahasiswa meningkat. Untuk lebih meningkatkan hasil, maka dikemukakan beberapa saran yaitu: 1) Dalam menerapkan model pembelajaran based learning, hendaknya dirancang suatu media atau sarana yang tepat sesuai dengan materi yang disajikan, 2) Sebelum perkuliahan dimulai, hendaknya dosen menjelaskan motede pembelajaran yang akan dilakukan dan meminta mahasiswa berpartisipasi secara aktif. 3) Model pembelajaran based learning ini, dapat juga dicobakan pada matakuliah lainnya. 
DAFTAR RUJUKAN

Abdurrahman, M. 2003. Pendidikan

Bagi Anak Berkesulitan

Belajar. Jakarta: Penerbit Rineka Cipta.

Arends, Richard I. 2008. Learning to

Teach. Yogyakarta: Penerbit

Pustaka Pelajar.

Arikunto, S., dkk. 2008. Penelitian

Tindakan Kelas. Jakarta:

Penerbit Bumi Aksara.

Hasugian, Turian. 2009. Penerapan

Pendekatan Kontekstual

Berbasis Masalah untuk

Meningkatkan Kemampuan

Pemecahan Masalah

Matematika Siswa SMA.

Medan: Skripsi FMIPA

UNIMED.

Lie, Anita. 2004. Cooperative

Learning di Ruang-ruang

Kelas. Jakarta: Penerbit

Gramedia Widiasarana

Indonesia.

Noor, Firmansyah. 2005. Pengaruh

Pembelajaran Kooperatif

Tipe STAD terhadap

Kemampuan Siswa dalam

Mengerjakan Bukti dalam

Matematika pada Siswa

SMU,(http://pagesyourfavorit

e.com/ppsupi/abstrakmat200

5.htm).
Sardiman. 2005. Interaksi dan Motivasi Belajar Mengajar. Jakarta: Penerbit Rajawali Pers.

Slameto. 2003. Belajar dan Faktorfaktor yang Mempengaruhinya. Jakarta: Penerbit Rineka Cipta.

Tim MKPBM. 2001. Strategi Pembelajaran Matematika. Bandung: Penerbit JICA UPI.

Trianto. 2007. Model-model Pembelajaran Inovatif Berorientasi Konstruktivistik. Jakarta: Penerbit Prestasi Pustaka.

Uno, Hamzah B. 2008. Perencanaan Pembelajaran. Jakarta: Penerbit Bumi Aksara.

Usman, Uzer. 2006. Menjadi Guru Profesional. Bandung: Penerbit PT Remaja Rosdakarya.

Widianti, Lilis. 2009. Problem Solving dalam Matematika. (http://newspaper.pikiranrakyat.com)

Zainurie. 2007. Pakar Matematika Bicara Tentang Prestasi Pendidikan Matematika Indonesia. (http://zainurie.wordpress.co $\mathrm{m} / 2007 / 05 / 04$ ) 